\title{
Policy Determination in E-Budgeting Implementation by the Government of DKI Jakarta - Indonesia
}

\author{
Abdul Hakim ${ }^{1, *}$, Ondy Asep Saputra ${ }^{2}$ and Choirul Saleh ${ }^{2}$ \\ ${ }^{1}$ Administrative Science in the Faculty of Administrative Sciences, Brawijaya University, Malang, Indonesia \\ ${ }^{2}$ Administrative Sciences Postgraduate Program Faculty of Administrative Sciences Brawijaya University, \\ Malang, Indonesia
}

\begin{abstract}
This research discusses and analyzes the deep comprehensiveness of the process of determining and implementing the E-Budgeting Policy by the Government of the Jakarta Migrant Workers; Research methodology uses a qualitative approach. The research results reveal the effectiveness of the role of actors in the process of implementing EBudgeting policies determined by several factors, namely: the level of understanding of budgeting procedures and mechanisms (APBD), activeness in providing input in the initial process (Musrenbag), and the ability to accommodate the interests of constituents into programs and concrete activities in the RKPD; the legislative role in implementing EBudgeting can be mapped out by looking at the actions of the executive and executive, namely: first, the interaction of non-professional making models, is a form of meeting between the executive and the legislature to use the power and authority, use of the budget, process and use; secondly, the associative systemic pattern, is a model of executive and legislative relations that is influenced by political, economic, and social systems, so that the process of formulating the General Budget Policy (KUA) and the Budget Priority and Platform (PPAS) is not value-free because it is influenced by the interests and demands of various interest groups. If there are interests from groups that have more political resources and political power compared to other groups, then they are likely to influence budget decisions.
\end{abstract}

Keywords: Policy, E-Budgeting and Government.

\section{INTRODUCTION}

In the era of globalization that we are addressing now has provided a variety of amazing sophistication in the form of technological sophistication in information and communication technology. At present the new terminology in Khazan Impossible knowledge, namely electronic government (e-Gov) which is the benefit of technology in the form of the internet in government activities. Electronic government or electronic government refers to the process of delivering information and online services via the internet or other digital devices. As stated in the definition given by the United States Federal Government: "e-government refers to the delivery of government information and services online through the internet or other digital means". Indrajit (2002: 3). In fact, it is not only limited to the delivery of information, but e-government also designs computerization for handling operational activities in organizations, computerization of services to the community, and integrating services provided by the government and private sector entrepreneurs. As the definition of e-gov given by the Government of Italy, as follows:

One part of e-government is the E-Budget policy as a means of improving the quality of public budgeting

*Address correspondence to this author at the Administrative Science in the Faculty of Administrative Sciences, Brawijaya University, Malang, Indonesia; E-mail: a.researcher40@yahoo.com services, increasing transparency, efficient administration costs, and at the same time empowering the parties involved as users in the use of e-Budgeting, so as to ensure transparency, administration and administration, and at the same time empower the parties involved in the implementation of good governance and budget. E-Budgeting is a financial system that is stored online with transparent transparency for all parties. This system is implemented as a budgeting documentation in a region. Everyone can access the budget data compiled by a regional government so that it can be expected to prevent embezzlement of funds or less from bureaucracy.

To realize good governance, the DKI Jakarta Regional Government has implemented a 2013 EBudgeting system, which is a follow-up to the implementation of Presidential Decree Number 3 of 2003 concerning the National Policy and Strategy for the Development of e-Government, which aims to create clean, transparent, accountable government, free from corruption and future collections of the Jakarta Provincial Government. The policy is regulated through the Regulations of the Governor of the Province of DKI Jakarta, Number 145 of 2013 concerning the Preparation of the Regional Income and Expenditure Budget / Budget Amendment and Regional Expenditures Changes through Electronic Electronic Budgeting. However, there are still a number of normative problems (normative problems), which 
have not been a number of equal visions from stakeholders in the implementation of the 2013 Capital System, the Government of the Republic of Indonesia. who aims to create a clean, transparent, accountable, free from corruption and collusion government in future DKI Jakarta Provincial Government budgets. The policy is regulated through the Regulations of the Governor of the Province of DKI Jakarta, Number 145 of 2013 concerning the Preparation of the Regional Income and Expenditure Budget / Budget Amendment and Regional Expenditures Changes through Electronic Electronic Budgeting. However, there are still a number of normative (normative problems) problems, which have not been the same equality of stakeholders in the implementation of the Governor Regulation, which can be seen from the problem of the occurrence of "disputes" between the executive and the legislature in the implementation process.

The problem that arises is the implementation and role of the model, the model in the implementation of $\mathrm{E}$ Budgeting, as well as the mechanism that is not yet compared directly to the demands of the community. This is what makes researchers interested in conducting this research about the implementation of Presidential Decree No. 3 of 2003 which is manifested in the form of E-Budgeting by the Government of the Special Special Region (DKI) of Jakarta. In addition, there is a conflict of opinion between the DKI Provincial Government and the DKI DPRD in the problem of implementing E-Budgeting, which has made the robotics look at the importance of this research. That was caused by the polemic between the DKI Jakarta Regional House of Representatives and DKI Jakarta Governor Basuki Tjahaja Purnama alias Governor (Erianto, 2015).

Chaotic APBD DKI Jakarta is actually the peak of disputes between the Governor and the members of the DKI Jakarta Parliament. Far before the parties had also been tense over the management of Jakarta and political views. Based on Kompas notes, there were at least four events that caused tensions between the Governor and the DPRD. Tension took place in midOctober 2014 when the Governor became the Acting Governor of DKI Jakarta. Referring to the Government Regulation in Lieu of Law Number 1 of 2014 concerning Election of Governors, Regents and Mayors, the election of the replacement governor should be conducted by the DPRD. This is based on the Government Regulation which states that the regions that stop or terminate the remaining terms of service for more than 18 months, so that the election of the replacement regions is made through the DPRD. Responding to that, the Governor said, Jakarta which is a Special Region of the nation's capital.

E-Budgeting provides a solution to the demands of the community so that members are targeted and can be accessed easily by the public through technology. The objective and useful cooperation methods are to eliminate the budget disbursement of the APBD. The E-Budgeting System that is implemented cannot be changed anymore, even the Regional Financial Management Agency (BPKD) at once does not understand how to make and apply it because it has been locked. The E-Budgeting System will maintain the program of activities that have been organized by the Regional Government Work Units (SKPD) not to be instigated by members of the Regional People's Representative Council (DPRD). However, it is acknowledged as a breakthrough in financial policy in the area, the use of E-Budgeting remains a weakness, which is related to the system's interruption of hackers or from online viruses that can damage data. Therefore, it can be known that in this research, we will discuss the problems regarding how. What are the determinations of policies and what are the measures in the process of implementing the Budgeting Policy in the DKI Jakarta Government?

\section{RESEARCH METHODS}

\section{Research Design}

This research is a qualitative study that examines the phenomenon of the E-Budgeting implementation process in the Special Regional Government of the Capital of Jakarta. Through the use of this qualitative approach, it enables communication of researchers and research subjects and a shared understanding of the phenomenon under study, both by the researcher and researcher (Cresswel, 1994; Babbie, 2004). The aim is to collect and analyze descriptive data in the form of writing, expressions of people and observed behaviors (Strauss and Corbin, 1997). Whereas the research problem was answered through an explanation of the research question based on the data in the field that had been interpreted by the theory presented in the literature review.

There are a number of reasons why researchers use qualitative research approaches in this dissertation research, namely:

1) The study of the implementation of the EBudgeting Policy in the DKI Jakarta Government, 
involves a relatively large number of stakeholders, and because of this study not only has to do with the budgeting process, but also concerns the behavioral and cultural aspects of the actors involved in the implementation of the E-Budgeting process. For example, it relates to the roles of executive budgeting committee, DPRD budget committee, and factors that hamper the implementation of E-Budgeting policies. In this research, there was no hypothesis that was determined early, no treatment (treatment), and no limitation to the final output of this research.

2) The purpose of this research is colored by the interaction between areas. In order to make the interactive activities for the researchers they are told to interact directly with the informants, among others by interviewing and observing in the background (according to their observations, not to the process, not to the purpose). Thus, research data are obtained through researchers as mediators, which are always responsive to the context. This research is in accordance with the naturalistic paradigm that combines the assumptions of the influence of researchers with information.

3) The issue of implementing the E-Budgeting Policy by the Regional Government, is not only about proportional knowledge, but also involves knowledge that cannot be tacit (tacit knowledge), which is difficult to obtain through the approach of rationality or quantitative knowledge. By using a qualitative approach, researchers hope to be able to reconstruct the informants of the informants as well as the complete and complete explanation of the phenomenon in the field.

4) Qualitative approaches can provide more complex details about phenomena that are difficult to express by quantitative methods (Mardalis, 2003). This also includes research that is being investigated on the implementation of e-budgeting policies. This research requires a lot of data mining in the field rather than measurements as in quantitative research. Data mining referred to is information obtained from various informants who know and experience the process of utilizing E-Budgeting in the preparation of the DKI Jakarta Government's APBD.
This type of research is a case study, with the following reasons: first, so that research results can provide important information about the observed interreality relations, and the processes that occur in the process of implementing E-Budgeting policies, the role of actors or stakeholders in implementing the policy, as well as the factors that support and hinder the process can be deepened in its explanation and understanding. Second, through the case study approach, there is an opportunity to gain insight into the meaning given by the actors in the process of implementing E-Budgeting policies, so that researchers can find the interrelationship between the roles of actors in the policy implementation process. Third, through case studies, researchers can build recommendations for implementing E-Budgeting policies that are considered ideal and applicable, based on an analysis of the existing models of the cases studied.

\section{Research Focus}

The focus of this research is to sharpen the ability of researchers in conducting an in-depth analysis of research problems. In accordance with the research problem that has been formulated, the focus of this research is as follows:

1. The process of implementing E-Budgeting policies in the DKI Jakarta Government, which is examined from the factors of the implementation process at the level of the executive budget committee, and the implementation process at the legislative budget committee;

2. The role of actors in the process of implementing E-Budgeting policies in the Government of DKI Jakarta, as seen from: the role of the executive (SKPD, Bappeko, Administrator, Data Team, and other work units); and the legislative role (DPRD Budget Commission, and DPRD Secretariat);

3. Factors that support and hinder the process of implementing E-Budgeting policies in the DKI Jakarta Government, seen from: internal and executive factors supporting and inhibiting the legislative, as well as external and external inhibiting and supporting factors, namely from non-governmental organizations, and or from the mass media;

4. E-Budgeting policy implementation model that can create a clean, transparent, accountable government, free from corruption and collusion, 
which will be illustrated through the existing model that implements the ongoing policy; and also recommends an ideal model of the $\mathrm{E}$ Budgeting policy implementation process.

\section{Data Collection}

Data collection techniques used in this study are unstructured free interviews, meaning that there are no guidelines prepared in advance. Conduct nonparticipant observation, and study documents that are relevant to the research focus. In the process of collecting data, a humane approach between the researcher and the data source (informant) becomes the main instrument in this study. By using informants as research subjects, the data collection refers to the assumption that data sources can provide responses in the form of signs, adjustments, and responses to the environment. An explanation of each of these data collection techniques is presented in the description below.

A. Observation (Observation) In this study the researcher made passive participation, that is, the researcher came to the meeting place or other activities and did not actively participate (observation was not active or did not participate). The observations made were not structured, because the focus of the predetermined research was still possible to change. Through the use of observation, researchers obtain benefits, including the following:

1. Researchers are better able to understand the context of data in the overall organizational situation, so that a holistic or comprehensive view of the budgeting process can be obtained using E-Budgeting;

2. Researchers gain direct experience, so researchers can use an inductive approach, so it is not influenced by previous concepts or views. The inductive approach opens the possibility of making discoveries, especially those relating to political processes that occur in computer-based budgeting (E-Budgeting);

3. Researchers can see things that are less or not observed by others, especially people who play a role in the operationalization of the $\mathrm{E}$ Budgeting program, because the presence of researchers has been considered normal;

4. Researchers can find things that were not previously revealed by the informant in the interview, because they are sensitive or want to be covered because they can harm the name of the institution or individual, and so on, for example about "relations between the executive and legislative institutions in the budgeting process";

5. Researchers can find things that are outside the informants' perceptions, so that researchers obtain a more comprehensive picture;

6. Through observations in the field, researchers not only collect rich data, but also gain personal impressions, and feel the atmosphere of the social situation under study, particularly interactions between actors, both those in the executive budget committee and the legislative budget committee. The objective of observation in this study are:

a) Place, where interactions in the situation of budget planning and E-Budgeting take place; i.e. meeting room, workspace, work atmosphere;

b) Actors, or people who are playing certain roles as representatives of the government, representatives of executives, representatives of the legislature;

c) Activity or activities carried out by the actor in an ongoing situation, including work activities, meeting activities, and discussion and lobying activities by members of the DPR Commission and members of the budget committee.

B. In-depth Interview (Indepth Interview). Interviews were conducted to obtain field data that could not be accessed through observation activities. This interview is also intended to deepen the knowledge or understanding of the event being observed. This step is taken by researchers to avoid or minimize errors in interpreting the meaning of symbols or informant activities related to the research problem. By using this technique, data collection is more in-depth, complete, and accurate, thus helping researchers efforts to analyze research problems more sharply. Determination of informants in this study has been carried out since making observations, so there is no wrong choice. While in-depth interviews (indepth interviews) are conducted on informants to provide flexibility to explain and describe their opinions freely, not limited by the choice of answers as in structured interviews. In this study, interviews were conducted indepth, i.e. unstructured interviews and covered the 
overall focus of the study in detail. The interview starts from the key informant, and then continues to the other informant, by conducting triangulation.

d. Documentation. Documentation is done by copying, scanning, or photographing original documents, with the permission of the authorized officer. Documentation data used in this study are secondary data extracted from documents, consisting of: documents about the main tasks and functions of each actor in the implementation of E-Budgeting, the results of DPRD commission meetings and joint commission meetings that stored in the DPRD Commission Secretariat, reports related to the implementation of E-Budgeting, and other relevant documents.

\section{Data Source}

Basically, qualitative research emphasizes more on direct data from social phenomenon actors or people who know and or experience the phenomenon. Because it is more about building a framework and problems, anyone can become a source of data as long as it remains relevant to the research problem. However, the selection of data sources will largely determine the quality of the data obtained. However, of course this research does not rule out the possibility of new data sources if the problems in the field demand it. The sources of this research data are presented in the description below:

a. Event or activity. Sources of research data come from events or activities observed, namely activities from staff at the City Development Planning Board, data input activities by the Data Team, activities of budget committee meetings, commission meetings, joint commission meetings, and meetings between the regional government and the DPRD;

b. Informants. Key informants of this research are the Head of the City Development Planning Agency (Bappeko), the Chairperson of the Executive Budget Committee and the Chairperson of the DPRD Budget Committee, the Chairperson of the DPRD Budget Commission, and the Chairperson of the EBudgeting Implementation Team. Other informants were staff from the Bappeko Office, staff at the DPRD Secretariat, members of the EBudgeting Team, and members of the DPRD. In addition, in-depth interviews were also carried out with e-budgeting consultants of the DKI Regional Government, Head of Planning and Funding, Head of Sub-Regional Budget Planning, Directorate General of Regional Financial Development, and staff at the Ministry of Home Affairs. The selection of research informants used purposive sampling based on participation criteria in budget planning meetings, or had participated in activities related to budget planning and discussion, and had been involved in using the E-Budgeting program. In addition, researchers also selected informants using judgment sampling techniques, specifically for members of the executive budget committee, members of the legislative budget committee, as well as from NGOs and the mass media based on consideration of "ownership" of information related to the budget planning process and the implementation of E-Budgeting;

c. Documents. Sources of data in the form of documents consist of: E-Budgeting data input documents, E-Budgeting outputs, reports on budget discussion meetings, results of commission meetings and joint commission meetings that are stored in the DPRD Secretariat relating to APBD discussions, and other relevant documents. Other documents were also learned from electronic sources from the site: www.musrembang.jakarta.co.id and the DKI Jakarta Regional Government Web Portal at www.jakarta.go.id.

\section{Research Locations and Sites}

This research was conducted in DKI Jakarta, based on the following considerations:

a) The DKI Jakarta Government has carried out the e-Budgeting budgeting process, but there are problems in accountability and differences with the DPRD;

b) In general, the people of DKI Jakarta have not yet understood the context of E-Budgeting both in their implementation and responsibilities.

The research sites are the E-Budgeting Room, the DPRD Commission workspace, the Budget Committee workspace, the DPRD Secretariat room, the Regional Head and Deputy Regional Head workspaces, the Head of Bappeko Headquarters, and other sites in the 
form of electronic sources, namely: www.musrembang .jakarta.co.id and DKI Regional Government Web Portal at www.jakarta.go.id.

\section{Data Validity Test}

Testing the validity of qualitative research method data includes tests: credibility (internal validity), transferability (external validity), dependability (reliability), and confirmability (objectivity). Sugiono (2013), revealed that the data credibility test consisted of (1) extended observation or data collection period (prolonged engagement); (2) increased perseverance in observation (persistent observation); (3) triangulation (triangulation) of data sources and methods; (4) discussion with peers (peer debriefing), (5) negative case analysis; and (6) referential adequacy checks, namely the process of checking the data obtained by researchers to the data giver. You do this by asking back to the initial data source. The extension of observation is carried out if all the planned time is insufficient for data collection, because the researcher considers the required data to be insufficient. In practice, the researcher must extend the data collection period because of the Promoter's Team's suggestion to complete the data. Increased perseverance is in terms of observation, researchers do directly both during the budget planning process and the implementation of $\mathrm{E}$ Budgeting, as well as the discussion process in DKI DPRD Commission meetings. Triangulation is mainly done on data sources to check whether there are different answers from various sources or informants for the same question, also by checking the results of observations with interviews or with existing document data. Discussions with peers are carried out mainly with peers in the doctoral program, both those who have completed their studies and those who have not yet completed their studies.

Transferability testing is an external validity that indicates the degree of accuracy or the applicability of the results of the study, so the researcher in making his report has provided a detailed, clear, systematic and reliable description. To meet this standard, the researcher presents the profile of DKI Jakarta and also the profile of the instantiation that implements $\mathrm{E}$ Budgeting, both its structure and main tasks and functions.

Dependability testing is done by conducting an audit of the entire research process. If the researcher does not have and cannot show "traces of his field activities", the dependability of his research is doubtful. In practice in the field, the researcher traced the appropriateness of the field notes with the results of the interview with the informant, whether the existing notes were in accordance with what was intended by the informant. Likewise, the photos of the documentation presented were rechecked (Chase et al., 1992).

To meet the dependability test criteria, researchers have tried to present the results of this study by enriching scientific discourse and comparing with similar research or those relevant to the focus of this study. The last step uses the certainty criteria (confirmability), and to realize certainty over the results of this study the researchers have discussed with the promoter and co-promoter. Every stage in the writing of a dissertation or a concept produced from the field was consulted with the promoter and co-promoters as well as expert reviewers (Dissertation Examination Team). Thus obtained input to add certainty from the results of the study.

\section{Data Analysis}

The data collected was analyzed using Interactive Model data analysis techniques from Miles, Huberman, and Saldana (2014: 31-33), the analytical method used for the process of analyzing data obtained in the field and moving back and forth continuously during research take place. In practice, the method used is by combining interactively and circularly between data collection (data collection), data condensation (data condensation), data display (data presentation), and then draw conclusions and verification (drawing / verification). Presentation of data is the arrangement of a set of information that allows drawing conclusions and taking action and helps in understanding what happened and to do something, including deeper analysis or taking action based on understanding. If the data that has been presented, verified and concluded is still felt there are still irregularities, duplications and asynchronous between one another, then the data condensation stage will be resumed. In this study the data presented is synchronized or adjusted to the research problem, and to ensure that the data is coherent then it is detailed in the focus of the study.

Data condensation is a form of analysis that sharpens, pays attention to, focuses, discards, and organizes data in such a way that the final conclusions can be formulated and verified. Data condensation refers to the process of selecting, focusing, simplifying, abstracting, and / or changing data that emerges from field notes, interview transcripts, documents, and other 
empirical materials. With condensation, we make strong data. Condensation data occur continuously throughout the field research. The next steps of data condensation are: writing summaries, coding, developing themes, creating categories, and writing analysis notes. Data condensation is a process of transformation that continues until the fieldwork ends, that is, the final report is written. Therefore, in this study, if new categories are found in the research field, the focus of the study will be changed or adjusted (Alwasilah, 2002).

The second step in this analysis is data display (data display). In general, the display must be organized and informative, must be managed so that it can produce a picture of conclusions and actions. Based on this, the researcher can understand what is happening and what must be done, both in terms of further analysis or taking action based on the understanding that has been obtained. Like data condensation, creating and using data views is an inseparable activity from the analysis and is part of the analysis. Designing data views, making rows and columns of a matrix or table for qualitative data, and deciding which data should be included in the tables is an analysis activity. In this study, the results of interviews relevant to the focus were chosen to be presented by looking at variations in sources, meaning not only from executive actors, but also from legislative and other actors related to the process of implementing E-Budgeting policies in the DKI Jakarta Government. Likewise, the researcher chooses relevant secondary data obtained from report documents of commission meeting reports, Data Team reports, as well as secondary data that has been processed in advance (sorted and simplified), so that it is easily understood in its presentation. The next circulation of this analysis activity is describing and verifying. Starting from the collection of data, qualitative researchers interpret things as happening by noting patterns, explaining, looking for causes and formulating propositions. The final conclusions may not appear until the data collection is complete, depending on the size of the field notes, coding, storage, the method used, the expertise of the researcher and the time limit needed to be met.

The three types of analysis activities and data collection activities are interactive cycle processes. Researchers continue to move between these four activities, namely during data collection and then proceed between condensation, display, and drawing conclusions / verification at the end of the study period.
From the beginning of the data collection, the researcher looks for the meaning of the interactions that occur, noting the regularity of the explanation, possible configurations, causal flow, and propositions. "Final" conclusions may not emerge until the data collection ends, depending on the size of the collection of field notes, their coding, retention and retrieval methods used, availability of research time, and availability of funds. Data coding, for example (condensation data), creates new ideas about what should be done up to the data matrix (data display). Entering data requires condensation data. As with filling in matrices, making initial conclusions, researchers also make decisions, for example, to add columns to the matrix to test conclusions. Analysis of qualitative data is essentially continuous and always repeated. Discussion of data condensation, display, and consecutive conclusions / verification as data analysis steps that follow one another (Aderson, 1979).

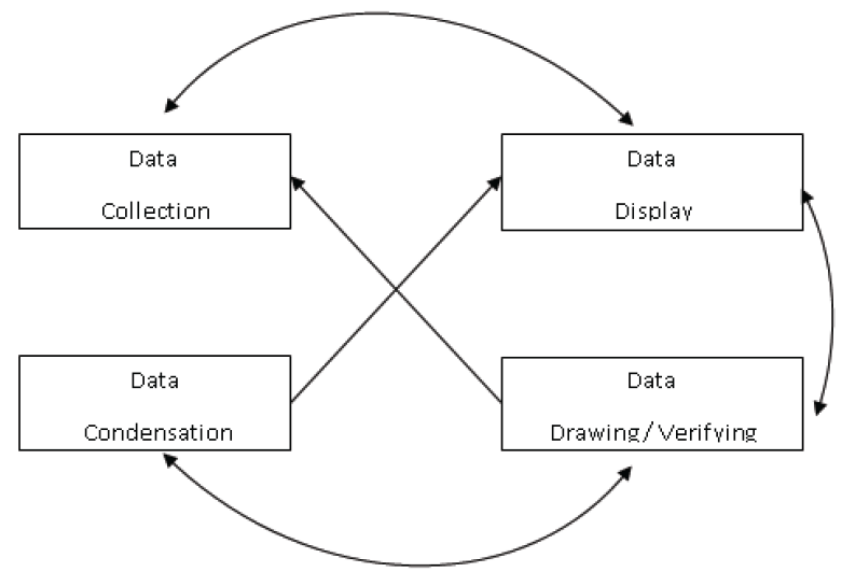

Figure 1: Components of Data Analysis: Interactive Model.

Source: Matthew B. Miles, et al., Qualitative Data Analysis: A Sourcebook Methods. Singapore: SAGE Publications Inc., 2014: 33.

\section{RESULTS AND DISCUSSION}

\section{Research Result}

Actors are those who are at the center of the health policy framework. These actors usually influence the process at the central, provincial and / city level. They are part of the network, sometimes also called partners to consult and decide on policies at each of these levels. The relationship of the actor and his role (his power) as a decision-maker is very much dependent on political compromise, rather than on matters in the policy debates that make sense.

The policy is about process and power. Health policy is effective if at the maximum level it can be 
implemented at a low cost. Efficiency in this case because the government has a limited investment to strengthen health status. So it is very important to allocate these resources to people in need and of course based on the available evidence.

a) Executive Roles: SKPD, Bappeko, Administrators, Data Teams, and Other Work

\section{Units}

The role of actors, especially executives in the implementation of E-Budgeting policies, can be seen from the actors' orientation in the formulation of public policies based on the following thoughts: (1) that the process of formulating public policies needs to carefully consider the existence of orientation and the interests of the actors involved as stakeholders of the policy (2) the fact that the level of bargaining and socioeconomic background of each actor is not the same, (3) participatory public policy is a paradigm that can be realized through an intensive process of orientation between actors that allows shifting patterns of attitude and orientation as forms of accommodation between the actors involved. The relationship between the regional government and the DPRD is a working relationship that has an equal and partnership position. Equal position means that among the regional government institutions it has the same and equal position, meaning that it does not supervise each other. Seeing the interaction between actors in the implementation of E-Budgeting policies in DKI Jakarta seen from three ways, namely the pattern of cooperation (bargaining), persuasive models (persuasion) and direction (com-manding) (Dwiyanto, 2015).

So to analyze the Executive and Legislative Relations Patterns in the 2017 DKI Jakarta Regional Budget discussion, the General Budget Policy (KUA) Stages and Provisional Budget Priorities and Plafonds (PPAS) will find forms of opposition that always have a negative impact and always contradict with the pattern of institutional relationships between the executive and legislative branches. This is as explained by ABD, as follows:

"... the pattern of Executive and Legislative Relations in the discussion of the 2017 DKI Jakarta Regional Budget in the General Policy Stages of the Budget (KUA) and the Priority and Temporary Budget Ceiling (PPAS) will find forms of opposition that always have a negative impact and are always contrary to the pattern of relations between the executive and legislative institutions institutionally ... the forms of conflict that arise in the administration of government are patterns of political conflict that involve various kinds of interest groups to make the Budget Priority an object of particular group interest ". (Interview, May 2017).

The forms of conflict that arise in the administration of government are patterns of political conflict that involve various interest groups to make Budget Priorities as an object of particular group interest. The pattern of relations that occurs in DKI Jakarta Province is the pattern of decessional relations in the form of Associative is a form of interaction of interests between the Government and the DPRD which was formulated at the RKA-PPAS APBD stage. interaction patterns between institutions can be done in the form of bargaining of interests that can take place through the form of accommodation such as coercion in which the Government of DKI Jakarta is forced to accommodate the interests of the DPRD with a view to reduce institutional pressure on the Legislature in the Budget policy formulation process. Based on the results of interviews in the research, it shows that the pattern of contradictions that occurred during the formulation of the 2017 DKI Jakarta Regional Budget, the DPRD always uses the power of authority to influence the political decisions to be decided, as stated by the PD, as follows:

"In the discussion of the DKI Jakarta Provincial Budget for 2017 Fiscal Year, which was preceded by the submission of the General Budget Policy (KUA) and the Provisional Budget Priority and Platfom (PPAS) directly submitted by the Provincial Government, represented by the Deputy Governor. However, the surrender carried out by the Government has passed the specified schedule, whereas actually on the 20th of June the discussion of RKA-PPAS in the DPRD has been included. (Interview, August 2017).

Problems that occur in DKI Jakarta Province In the discussion of the 2017 DKI Jakarta Regional Budget, during the process of gathering the aspirations of the people, the selection model of the Development Consultation began at the Kelurahan, Subdistrict level, 
up to the Provincial level. From this mechanism, both the DKI Jakarta Provincial Government and the DPRD must make every effort to raise public policy issues that are the needs of the community. The selection process carried out by the DPRD will be a fundamental foundation in formulating the KUA-PPAS together with the screening results conducted by the Provincial Government of DKI Jakarta.

The regional government as an agent to draw up the APBD Conceptual Framework has weakened the strength of the DPRD as the principal in conducting discussions at the KUA-PPAS Level which already contained the respective SKPD programs in the following fiscal year. The space for the DPRD to take a closer look is the discussion of the KUA and PPAS and is not involved in the preparation of the RKA SKPD. Therefore, it is easy for the interests of the local government to be accommodated, including reducing the scale of priorities in the preparation of the SKPD RKA for the 2017 APBD budget year. The actions of the local government have violated contracts due to agency problems such as selfish behavior, limited rationality and risk aversion, asymmetric information between the principal and agent, and the presence of information and data monopolies by agents (Aditya et al. 2020).

This proves that the executive lacks commitment in complying with the APBD preparation schedule, causing delays in submitting the RAPBD to the DPRD. RAPBD prepared Based on the table above, the delay in submitting the RAPBD to the DPRD was largely due to the delay in signing the KUA-PPAS memorandum, but the ladder of executive interest in the preparation of the RAPBD was also a cause which ultimately took a long time to prepare. This is very evident in the preparation of the RAPBD for 2010 which takes almost 3 months 25 days, and in 2017 which takes almost 4 months 21 days, whereas the deadline according to Permendagri 13 of 2006 is only 8 weeks. This proves that the executive lacks commitment in complying with the APBD preparation schedule, causing delays in submitting the RAPBD to the DPRD. The RAPBD that has been prepared is then submitted to the DPRD for discussion. Meanwhile, to analyze the views of the Government and DPRD regarding the substance and context of the DKI Jakarta Provincial Budget, based on the results of interviews with SL, an informant at one of the OPD in DKI Jakarta, it was said that:

"In the preparation of the 2017 DKI Jakarta Provincial Budget from the discussion stage, the work programs in each Regional Work Unit (SKPD) have been questioned related to the substance of the budget discussion, because at the time the KUA-PPAS submission process from the TPAD Team did not submit a draft from each SKPD. So that the legislature still refuses to discuss the APBD at the next stage, because indeed the SKPD must submit a draft program that will be the basis for preparing the 2017 APBD. "(Interview, August 2017).

Based on the results of the interview that the 2017 APBD discussion there was a conflict of interest between the Executive and Regional Legislative actors in looking at the substance of the budget presentation which would be decided at the plenary meeting carried out by the regional legislature. The pattern of behavior of political actors that occurs in the results of studies conducted is that the discussion of the Draft Regional Budget (APBD) has not run according to the mechanism applied, starting from the KUA discussion, in the PPAS discussion, the plenary of the Regent's explanation of the RAPBD and the Financial Note, plenary of the faction's view of the Financial Note, discussion of RKA-SKPD at the Budget committee level, discussion of commission level, budget alignment at the committee level at the budget committee level, plenary for the determination of budgetary regulations. The main reason that policy actors, especially from the regional government side proposed an income budget to be implemented for 2017, is that the proposed revenue and expenditure budget always asks for opinions and responses from the bottom up to be discussed at the maturation stage of programs and projects through the RAPBD. If you pay attention to what happened at the time the observation was made as stated above, it can be explained that the process of formulating the RAPBD policy was in fact carried out in accordance with the mechanism previously determined.

Based on the explanation of the role of actors in the process of implementing E-Budgeting policies of the DKI Jakarta government, especially the role of the executive can be concluded as follows:

(a) The role of actors, especially executives, in implementing E-Budgeting policies can be seen from the orientation of actors in the formulation of public policies based on the following thoughts: (1) that the process of formulating 
public policies needs to carefully consider the existence and orientation of the actors involved as stakeholders of the policy to be made, (2) the fact that the level of bargaining and socioeconomic background of each actor is not the same, (3) participatory public policy is a paradigm that can be realized through an intensive process of orientation between actors that allows shifting patterns of attitude and orientation as a form of accommodation between the actors involved;

(b) The relationship between the regional government and the DPRD is a work relationship of equal standing and partnership. Equal position means that among the regional government institutions it has the same and equal position, meaning that it does not supervise each other. Seeing the interaction between actors in the implementation of E-Budgeting policies in DKI Jakarta seen from three ways, namely the pattern of cooperation (bargaining), the persuasive model (persuasion) and direction (com-manding);

(c) Related to the role of actors in the process of implementing the DKI Jakarta government's EBudgeting policy, this can be seen from the pattern of interaction between the Regional Government and the DPRD in the KUA-PPAS discussion process.

(d) The relation pattern that occurs in DKI Jakarta Province is the decessional relation pattern in the form of an associative form of the interaction of interests between the Government and the DPRD which was formulated at the RKA-PPAS APBD stage. interaction patterns between institutions can be done in the form of bargaining of interests that can take place through the form of accommodation such as coercion in which the Government of DKI Jakarta is forced to accommodate the interests of the DPRD with a view to reducing institutional pressure on the Legislature in the Budget policy formulation process;

(e) An anticipative pattern of associative reaction arises in the relationship between the executive and the legislature in implementing E-Budgeting policies. This relation pattern is a model of the form of interaction that occurs in the form of cooptation, in which the local government accepts the authority of the DPRD to maintain the stability of the regional government. Forms of interaction also exist in the form of accommodation interactions, namely the form of coercion or on the basis of the local government's compulsion to reject or accept the interests of the legislative elite;

(f) Non-professional associative interaction patterns, where the interaction pattern of nonprofessional making models is a form of meeting between the Executive and Legislative institutions to use the power of their authority or resources in order to influence decision making, both in terms of the substantial and context of the 2017 Budget Year Budget. interaction patterns used include the dissemination of public issues, issues of interest groups to support or oppose the Budget preparation process (Mardalis, 2003).

b) Legislative Role: DPRD Budget Committee, and DPRD Secretariat

The legislative role in the process of drafting the RAPBD by using E-Budgeting begins with the issuance of the Governor's circular concerning the preparation of the Work Plan and Regional Work Unit Budget (RKASKPD). In the preparation of the SKPD's RKA in the DKI Jakarta Provincial Government in 2017, it has not used its authority and power to the maximum, this has caused the reasonableness of spending on the activity program to be based only on the compiler's perceptions and verifiers. Problems in internal SKPD also slow down in the preparation of the RKA-SKPD, namely poor coordination within the SKPD in the preparation of the RKA-SKPD, difficulties from the SKPD in preparing work performance-based budgets as outlined in the RKA-SKPD and a lack of understanding of the SKPD towards regulations on budgeting. Regulations related to funds from superiors' government which were late to be issued and changed both allocation and allocation were also a problem in the preparation of the RKA-SKPD, not only in the preparation of the KUA-PPAS draft. This is as stated by the KBA, as follows: "... the legislative role in the process of drafting the RAPBD by using E-Budgeting begins with the issuance of the Governor's circular concerning the preparation of Work Plans and Budgets of Regional Work Units (RKA-SKPD). In the preparation of the RKA SKPD in the Provincial Government of DKI Jakarta in 2017, it did not use its authority and power to the maximum, this caused the 
reasonableness of spending on the activity program to be based only on the perceptions of the compiler and verifier. Problems in internal SKPD also slow down in the preparation of the RKA-SKPD, namely poor coordination within the SKPD in the preparation of the RKA-SKPD, difficulties from the SKPD in preparing work performance-based budgets as outlined in the RKA-SKPD and a lack of understanding of the SKPD towards regulations on budgeting. ... "(Interview, May 2017).

The discussion process, both the executive and legislative branches, make additions or subtractions to the program activities listed in the RAPBD, often even adding activity programs that are not listed in the General Budget Policy (KUA) and Prioritization and Temporary Budget Platform (PPAS). This of course contradicts what has been stipulated in Permendagri 13 of 2006 which states that the discussion of the RAPBD is emphasized on conformity with the agreed KUA-PPAS.

The postponement of the meeting after three days failed to take place. This results in the 2017 discussion that the DKI Jakarta Provincial Budget is only stipulated by the DKI Jakarta Provincial Governor Regulation. Because of the reference in the RAPBD discussion mechanism in DKI Jakarta Province, the nature of DPRD Budget Board meetings is closed, whereas DPRD Commission meetings are open and can be declared closed, but in reality the commission meetings are always declared closed. This is as stated by KBA, as follows:

"... the lack of commitment to the presence of the legislature did not only occur in the process of discussing the KUA-PPAS draft, even in the RAPBD discussion process it did occur, which resulted in the postponement and postponement of the discussion meeting. Even during the plenary meeting to sign the approval of the RAPBD also occurred. This was very clear at the plenary meeting of approval of the 2017 RAPBD, the plenary meeting failed to take place due to the lack of quorum meetings where the meeting was only attended by 12 DPRD members from 20 DPRD members so that it did not meet $2 / 3$ of the DPRD members. Although the delay has been carried out up to two times with a grace period of 5 and 10 minutes .... ". (Interview, May 2017).
The RAPBD discussion is also influenced by the dynamics of the relationship that occurs between the executive and legislative branches. Relationships that occur in the discussion of the DKI Jakarta Province RAPBD are less harmonious where coordination, cooperation and communication between the executive and the legislature are not going well, so the discussion process is disrupted. Inharmonious relations also occur in the DPRD internally, this is clearly seen in the discussion process of the Regional Regulation on the 2017 Regional Budget (APBD), where the DPRD leaders disagree with each other and have different opinions on the implementation of the discussion. Of course, this has made the internal coordination in the DPRD not going well too. In addition, there is legislative distrust of the executive in preparing the RAPBD. Among DPRD members felt that not all of the funds listed in the RAPBD were submitted to the DPRD. Besides this, the capacity and competence of DPRD members in the discussion also affect the speed in the discussion as well as the quality of the results of the APBD discussion. This was admitted by a DPRD member who stated that it was related to the educational and social background of the DPRD member. This is as stated by KBA, as follows:

".... The discussion of the RAPBD is also influenced by the dynamics of the relationship that occurs between the executive and legislative branches. Relationships that occur in the discussion of the DKI Jakarta Province RAPBD are less harmonious where coordination, cooperation and communication between the executive and the legislature are not going well, so the discussion process is disrupted. Inharmonious relations also occur in the DPRD internally, this is clearly seen in the discussion process of the Regional Regulation on the 2017 Regional Budget (APBD), where the DPRD leaders disagree with each other and have different opinions on the implementation of the discussion. Of course, this makes the internal coordination in the DPRD not going well too ... ". (Interview, May 2017).

The process occurred in the discussion of the 2017 DKI Jakarta Regional Budget, namely from the preparation of the KUA-PPAS which carried out the preparation of regional development priorities could not be carried out fully among others due to constraints of limited development funds, time and human resources. 

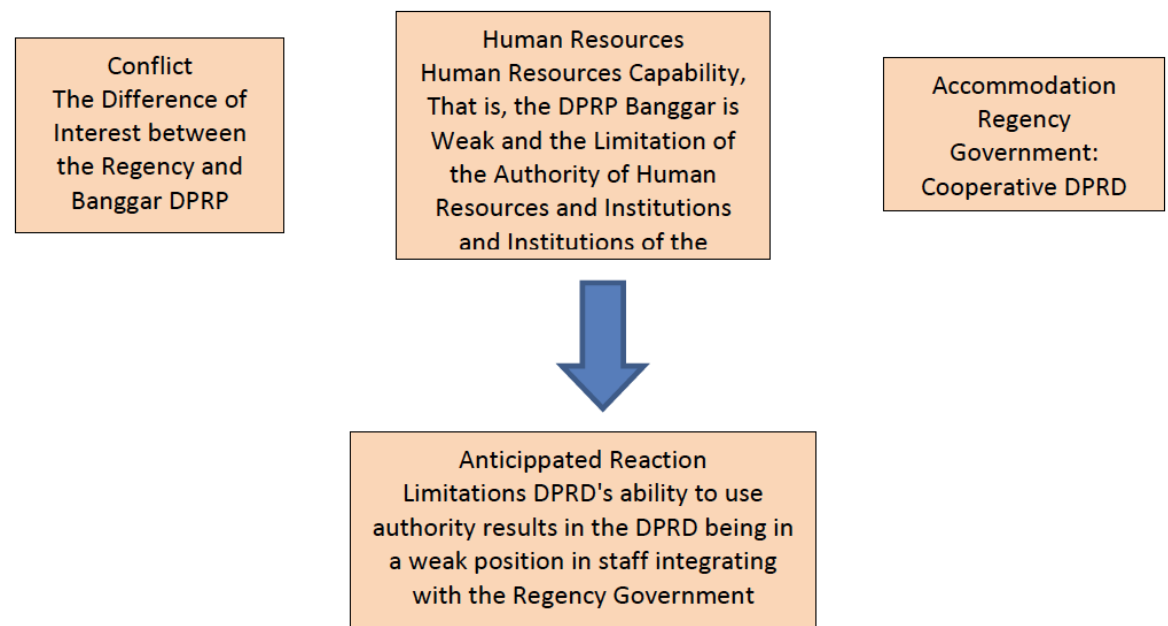

Figure 2: Executive and Legislative Relationship Pattern in the Discussion of KUA-PPAS of DKI Jakarta Province.

Therefore, the regional development priorities of DKI Jakarta Province must be projected so that they can deal with the problems faced optimally. There are a number of SKPD work programs that are being debated at the commission level, namely in the department of Public Works, the Department of Transportation, Bappeda and R\&D.

In this context, in the preparation of DKI Jakarta Province KUA-PPAS in 2017. There are different views on the substantial programs compiled by each SKPD, whereas the budgeting mechanism using a performance approach is based on budget priorities and ceilings which are scales to increase productive programs or activities in the community. Improvement of main programs or activities for the Regional People's Declaration of the Council (DPRD) should be given the opportunity to prepare and submit program plans, activities and budgets for one budget year each in accordance with the main programs and activities that have been set during the recess in the community.

Based on the table above, outlining the pattern of executive and legislative relations is very simple, namely, the legislative body is present to make policies while the executive agency to conduct policies. The description above explains that in the discussion of the APBD budget from the KUA-PPAS stage to the APBD ratification, it is very visible the pattern of relations between the hierarchy of authority and political supremacy. So with the increasing role of the executive in discussing the budget, the authority of legislative political supremacy can be administered to the interests that develop in the courtroom.

a) Image of facts of interest: departing from the view of both the legislative and executive agree in the discussion of the APBD, but with different agreements. In the APBD discussion that began with the KUA-PPAS conducted by the regional government budget team (TPAD), executives were needed in accordance with the facts and knowledge gained through the annual Musrenbang forum. So in each discussion, the APBD in the Budget Agency (Banggar) as well as the Commission, the legislative body tends to be based on the interests and values obtained during the recess in the electoral district (Dapil). Thinking about the difference between these two in different Perspective in expressing between administrative rationality and political rationality.

b) Energy image / equilibrium: departing from the agreement of both the legislative and executive are always in the discussion of the APBD, both of them mutually support political aspects. The pattern of legislative relations articulates broad interests in society and disorganized individuals with diffuse interests. While executive relations patterns only articulate the interests of organized clients. Interpretation of the different roles is the division of duties of the legislators. It seems very passionate, participant, idealistic and ideological. While executives take caution in making decisions, are centralized, practical and pragmatic. The legislature seeks publicity, raises innovative problems, and energizes budget policy. While executives do not seek "office" publicity and ask for conformity with budget policies.

c) Pure hybrid image: the last view approved by the election that appears in the budget discussion is 
Table 1: Executive and Legislative Stakeholder Mapping Relationship Patterns

\begin{tabular}{|c|c|c|c|}
\hline IMAGE & LEGISLATIF & EKSEKUTIF I & EKSPRES \\
\hline $\begin{array}{l}\text { Policy/ } \\
\text { APBD }\end{array}$ & $\begin{array}{l}\text { Make and Discuss } \\
\text { KUA-PPAS and RAPBD }\end{array}$ & $\begin{array}{c}\text { Propose APBD and Implement } \\
\text { APBD policy }\end{array}$ & $\begin{array}{l}\text { 1. Executive Patterns Always a } \\
\text { hierarchy of authority. } \\
\text { 2. Legislative Relations Pattern tends } \\
\text { to use Political Supremacy in viewing } \\
\text { APBD }\end{array}$ \\
\hline $\begin{array}{l}\text { Facts / Patterns } \\
\text { The importance }\end{array}$ & $\begin{array}{l}\text { 1. Relationship Patterns The } \\
\text { interests of their constituents are } \\
\text { filtered through the recess period. } \\
\text { 2. In the APBD Discussion at the } \\
\text { Commission Level, the DPRD } \\
\text { Banggar and the Political Sensitivity } \\
\text { RAPBD Discussion are very } \\
\text { prominent. } \\
\text { 3. Interaction relations to take } \\
\text { responsibility for their constituents. }\end{array}$ & $\begin{array}{l}\text { 1. Executives always prioritize } \\
\text { patterns of facts and budget } \\
\text { understanding or knowledge. } \\
\text { 2. Executives tend to be based on } \\
\text { neutral expertise. } \\
\text { 3. Executive Interaction tends to } \\
\text { rely on technical efficacy in the } \\
\text { formulation of Policies. }\end{array}$ & $\begin{array}{l}\text { 1. The legislature tends to suppress } \\
\text { accountability to its constituents. } \\
\text { 2. Legislative relations tend to be } \\
\text { Political Rationality. } \\
\text { 3. Executive relations tend to be } \\
\text { Administrative Rationality. }\end{array}$ \\
\hline $\begin{array}{l}\text { Energy / Eq } \\
\text { uilibrium }\end{array}$ & $\begin{array}{l}\text { 1. The legislature articulates broad } \\
\text { and disorganized interests. } \\
\text { 2. The legislature is very passionate, } \\
\text { participant, idealistic and ideological. } \\
\text { 3. The legislature tends to look for } \\
\text { prestige by raising problems in order } \\
\text { to provide energy. }\end{array}$ & $\begin{array}{l}\text { 1. Executives tend to articulate } \\
\text { interests to clients and are } \\
\text { organized. } \\
\text { 2. Executives tend to be careful in } \\
\text { making centralized and pragmatic } \\
\text { decisions. } \\
\text { 3. Executives tend to regulate } \\
\text { interests in land and provide a } \\
\text { balance to policies. }\end{array}$ & $\begin{array}{l}\text { 1. Participants } \\
\text { 2. Executives tend to be political }\end{array}$ \\
\hline $\begin{array}{l}\text { Hybrid } \\
\text { Pure }\end{array}$ & Same (Blending Characteristics & Same (Mixed Relationship) & $\begin{array}{c}\text { Politicize the Executive and } \\
\text { bureaucratization } \\
\text { Legislative }\end{array}$ \\
\hline
\end{tabular}

Source: Results of Field Analysis 2017

the legislative and executive mix in the budget formulation. This picture states that the budget does not see the pattern of legislative and executive roles in policy. However, what happened was the birth of the phenomenon of "pure hybrids", in short, could have happened "political bureaucratization and executive politicization".

So there are some images that can be drawn from the development of the roles of the two actors above, namely:

(a) In the policy initiation stage, executive influence is still quite large;

(b) Legislative interaction plays a more important role in conflict management than the executive, especially in managing conflicts that occur in the DPRD courtroom;

(c) In the planning, coordination and budgeting process the role of the executive is increasingly important. Legislative relations have a potential role in their allocation in the policy making process; (d) Executive and legislative relations play an important role in policy formulation, but the executive role pattern remains more dominant

Based on the explanation of the role of actors in the process of implementing E-Budgeting policies of the DKI Jakarta government consisting of executive and legislative roles, it can be concluded as follows:

(a) The role of actors, especially executives, in implementing E-Budgeting policies can be seen from the orientation of actors in the formulation of public policies based on the following thoughts: (1) that the process of formulating public policies needs to carefully consider the existence and orientation of the actors involved as stakeholders of the policy to be made, (2) the fact that the level of bargaining and socioeconomic background of each actor is not the same, (3) participatory public policy is a paradigm that can be realized through an intensive process of orientation between actors that allows shifting patterns of attitude and orientation as a form of accommodation between the actors involved; 
(b) The relationship between the regional government and the DPRD is a work relationship of equal standing and partnership. Equal position means that among the regional government institutions it has the same and equal position, meaning that it does not supervise each other. Seeing the interaction between actors in the implementation of E-Budgeting policies in DKI Jakarta seen from three ways, namely the pattern of cooperation (bargaining), the persuasive model (persuasion) and direction (com-manding);

(c) Related to the role of actors in the process of implementing the DKI Jakarta government's EBudgeting policy, this can be seen from the pattern of interaction between the Regional Government and the DPRD in the KUA-PPAS discussion process;

(d) The relation pattern that occurs in DKI Jakarta Province is the decisional relation pattern in the form of Associative is a form of interaction of interests between the Government and the DPRD which is formulated at the RKA-PPAS APBD stage. interaction patterns between institutions can be done in the form of bargaining of interests that can take place through the form of accommodation such as coercion in which the Government of DKI Jakarta is forced to accommodate the interests of the DPRD with a view to reducing institutional pressure on the Legislature in the process of formulating budget policies;

(e) An anticipative pattern of associative reaction arises in the relationship between the executive and the legislature in implementing E-Budgeting policies. This relation pattern is a model of the form of interaction that occurs in the form of cooptation, in which the local government accepts the authority of the DPRD to maintain the stability of the regional government. Forms of interaction also exist in the form of accommodation interactions, namely the form of coercion or on the basis of the local government's compulsion to reject or accept the interests of the legislative elite;

(f) Non-professional associative interaction patterns, where the interaction pattern of nonprofessional making models is a form of meeting between the Executive and Legislative institutions to use the power of their authority or resources in order to influence decision making, both in terms of the substantial and context of the 2017 Budget Year Budget. interaction patterns used include disseminating public issues, interest group issues to support or oppose the Budget preparation process;

(g) The role of the legislature in the process of drafting the RAPBD by using E-Budgeting begins with the issuance of the Governor's circular concerning the preparation of the Work Plan and Regional Work Unit Budget (RKA-SKPD). In the preparation of the RKA SKPD in the Provincial Government of DKI Jakarta in 2017 it has not used its authority and power to the fullest, this causes the reasonableness of spending on the activity program to be based only on the compiler's perceptions and verifiers;

(h) Internal SKPD problems also slow down in the preparation of the RKA-SKPD, namely poor coordination within the SKPD in preparing the RKA-SKPD, difficulties of the SKPD in preparing work performance-based budgets as outlined in the RKA-SKPD and lack of understanding of the SKPD against regulations regarding budget preparation. The regulations related to funds from superiors' government which are late in issuance and change both allocation and allocation are also a problem in the preparation of RKA-SKPD, not only in the preparation of the KUA-PPAS draft;

(i) Lack of understanding of both the legislative and executive branches of regulations regarding the preparation of the APBD may have caused this. One function of the DPRD is the budget function, which is a function to discuss and approve budgets proposed by the executive. In carrying out the budget function, the DPRD (legislative) places more importance on its interests, which is indicated in the addition of its program of activities and budget allocation, which is often not in line with the priorities and work plans of the SKPD;

(j) The legislative role in implementing E-Budgeting can be mapped by looking at the pattern of interaction with the executive. First, it is seen that there are associative non-decisional interaction patterns. The pattern of interaction of the Non-Professional Making model is a form of 
meeting between executive and legislative institutions to use the authority of their authority or the resources they have in order to influence decision making, both concerning the substantial and context of the 2017 Regional Budget. In addition, the form of interaction patterns used include the dissemination of public issues, the issue of interest groups to support or oppose the Budget drafting process. Second, is the pattern of associative systemic interaction. The Systemic interaction pattern is a model of the relationship between the executive and the legislature strongly influenced by the political, economic, and social systems. So that in the context of the executive and legislative regions in preparing public budgets, namely the preparation of the General Budget Policy (KUA) and the Priority and Budget Platform (PPAS) are not free of value from the interests and demands of various interest groups. The pattern of forming interests from one group that has greater political resources and power compared to other groups tends to influence budget policy decisions. Thus, in the practice of public sector budgeting in the DKI Jakarta Government, the influence of political factors in the DPRD factions, in particular, the fraction that deals with budget planning cannot be eliminated.

c) The Role of Actors in the Process of Implementing E-Budgeting Policies of the DKI Jakarta Government

Actors are those who are at the center of the health policy framework. These actors usually influence the process at the national, provincial and district / city level. They are part of the network, sometimes also called partners to consult and decide on policies at each of these levels. The relationship of the actor and his role (his power) as a decision maker is very much dependent on political compromise, rather than on matters in the ongoing policy debates. That is, political compromise more strongly influences the decisionmaking process than the technical decision-making procedures. The policy is about process and power. Health policy is effective if at the maximum level it can be implemented at a low cost. Efficiency in this case is difficult because the government has limited investment to strengthen health status. So it is very important to allocate these resources to people in need and of course based on the evidence.

The process of drafting up to the discussion of the Regional Revenue and Expenditure Budget always has an element of interest from both the executive and legislative branches. There are different interests and some are the same. Legislative interests can be classified into two, namely formal interests and informal interests. The formal interests are in the form of commitments from the internal meetings of the budgetary body and the informal ones are in the form of the interests of the supporting parties and their constituents. While the interests of the executive are normatively the focus of development which is then broken down in the Regional Government Work Plan.

\section{Executive Role}

The role of the executive in implementing $\mathrm{E}$ Budgeting policies in general is related to the budget. This is interpreted as a financial plan that reflects the policy choices of an institution or a particular institution for a period to come. Understanding the budget includes a general understanding, both the state budget, company budget and the budget of other institutions or institutions. In the regional scope, the budget is set forth in the Regional Budget (APBD) document. The budget is a very important planning process in terms of finance, because the budget will be a guideline in managing a state or regional finances in the future period. However, because the process of drafting and accountability of state or regional finances is inseparable from the involvement of representative institutions, the budget can be used as a monitoring tool for the community towards the government. So, it can be concluded that budgeting is a political activity, thus both the process and the product are political products.

Various interests, both political and power interests, have led to contestation on the one hand and compromise on the other in order to achieve the objectives of each actor which is a reflection of budget politics. It is seen here that budget politics is an attempt to fulfill various diverse and competing interests in the struggle for limited resources through rational formulations that can be accepted by all parties. Whether we realize it or not, this pattern of budget policy setting has ignored the principles of justice, propriety and distribution of the budget for equitable development. If this continues year after year, it will have an adverse impact on the development process in DKI Jakarta Province.

Based on the explanation of the results in the previous chapter, the role of actors in the process of implementing E-Budgeting policies of the DKI Jakarta 
government, especially the role of executives, can be seen that the role of actors, especially executives, in implementing E-Budgeting policies can be seen from the orientation of the actors in the formulation of public policy based on the following thoughts: (1) that the process of formulating public policy needs to carefully consider the existence of orientation and interests of the actors involved as stakeholders of the policy to be made, (2) the fact that the level of bargaining and socioeconomic background of each actor is not the same, (3) Participatory public policy is a paradigm that can be realized through an intensive process of orientation between actors that allows shifting patterns of attitude and orientation as a form of accommodation between the actors involved.

In the implementation of public policy, there is a model that can be used as an analytical tool in measuring the success of a policy. One of them is the policy implementation model from George Edward III. according to Edward III in Nugroho (2009: 513) to realize an effective public policy implementation it is necessary to pay attention to four aspects, namely: (1) Communication, in this case with regard to how the policy is communicated and the responsiveness of the parties involved; (2) Resources, in this case regarding the availability of supporting resources; (3) Disposition, regarding the willingness of the implementors to carry out public policies; (4) The structure of the bureaucracy, with respect to the suitability of the bureaucratic organization which is the organizer of the implementation of public policy. The relationship between the regional government and the DPRD is a working relationship that has an equal and partnership position. Equal position means that among the regional government institutions it has the same and equal position, meaning that it does not supervise each other. Seeing the interaction between actors in implementing E-Budgeting policies in DKI Jakarta is seen from three ways, namely the pattern of cooperation (bargaining), the persuasive model (persuasion) and direction (commanding).

Before the executive's interests are brought up in discussions with the Budget Agency, the budget team will discuss them first. The interests discussed included all community interests that came in through the Regional Development Planning Consultation (Musrenbang), the results of the Development Coordination Meeting (Rakorbang) and proposals from the Regional Work Unit both projects or programs and budgets.

\section{Legislative Role}

The legislative role in implementing the E-Budgeting policy is in the context of carrying out the oversight task of the implementation of the Regional Budget. DPRD, the only thing to remember is that this oversight is not an examination that has to punish executive institutions but rather oversight that is more directed to guarantee the achievement of the targets set in the APBD. Supervision is an integral stage with all stages in the preparation and reporting of APBD. Supervision is needed at each stage not just at the evaluation stage. Supervision carried out by the board begins at the time of the preparation of the APBD, APBD implementation, APBD changes and APBD accountability. Supervision of the APBD is important to ensure (1) budget allocation is in accordance with regional priorities and proposed for the welfare of the community, (2) ensuring that the use of APBD is economical, efficient and effective and (3) ensuring that APBD implementation is truly accountable or in words others that the budget has been managed transparently and accountably to minimize leakage. To be able to carry out oversight of the APBD, members of the board must have knowledge and experience about the budget starting from the mechanism of preparing the budget to its implementation (Sabaruddin, 2015).

Field data on the role of actors in the process of implementing E-Budgeting policies of the DKI Jakarta government especially in the role of the legislature is that the legislative role in the process of preparing the RAPBD by using E-Budgeting begins with the issuance of a governor's circular concerning the preparation of Work Plans and Budgets of Regional Work Units (RKA) -SKPD). In the preparation of the RKA SKPD in the Provincial Government of DKI Jakarta in 2017, it did not use its authority and power to the maximum, this caused the reasonableness of spending on the activity program to be based only on the perceptions of the compiler and verifier. The interests proposed by the Executive Budget Team to the Budget Agency, after program or project proposals from the Regional Work Unit and the interests of the community are discussed in the internal budget executive team. Furthermore, it is articulated as an executive interest that aims to improve the welfare of the community and is included in the Regional Work Plan Design. This Local Government Work Plan is valid for one year only.

The executive budget team brings proposals for each Regional Work Unit and the interests of the community that enter through the Regional 
Development Planning Consultation mechanism to be discussed together with the Legislative Budget Board. In addition there are interests of the council itself which is related to secretarial matters, whose submission through the secretary of the Regional Representative Council is then proposed to the Executive Budget Team. The proposal of each Regional Work Unit that has been developed has referred to the Bupati's Vision and Mission which is then elaborated into the Regional Government Work Plan. If in terms of the budget the executive interests are the proposed Regional Work Unit Budget listed in the General Budget Policy and Temporary Budget Priority Platfon. The interests of the Legislature, according to Napitupulu (2007) The Legislature as well as the executive has an interest in the preparation of the Regional Revenue and Expenditure Budget. The interests held by the legislature are slightly different from those of the executive although in broad terms can be said to be the same. If the interests carried by the executive are program and budget proposals from each Regional Work Unit and public interests that enter through the Development Planning Consultation process, starting from the village / village level to the district level. Whereas on the legislative side there are two interests namely, the public interest brought through the Community Aspirations Netting process which is carried out during recess three times and the interests originating from party missions, entrusted voters or in other words the interests of their constituents and the interests of work partners integrated into the commission.

The research findings presented in the previous chapter stated that the problems in the internal SKPD also slowed down in the preparation of the RKA-SKPD, namely poor coordination within the SKPD in the preparation of the RKA-SKPD, the difficulty of the SKPD in preparing a budget based on work performance as outlined in the RKA -SKPD and lack of understanding of SKPD on regulations regarding budget preparation. Regulations related to funds from superiors' government which were late to be issued and changed both allocation and allocation were also a problem in the preparation of the RKA-SKPD, not only in the preparation of the KUA-PPAS draft. Lack of understanding of both the legislative and executive branches of regulations regarding the preparation of APBD is the reason for this. One function of the DPRD is the budget function, which is a function to discuss and approve budgets proposed by the executive. In carrying out the budget function, the DPRD (legislature) places more importance on its interests, which is indicated in the addition of its program of activities and budget allocation, which is often not in line with the priorities and work plans of the SKPD. We can map the role of the legislative in implementing E-Budgeting by looking at the pattern of interaction with the executive. First, it can be seen that there are non-decisional associative interaction patterns. The pattern of interaction of the Non-Professional Making model is a form of meeting between the Executive and Legislative institutions to use the power of their authority or the resources they have in order to influence decision making, both concerning the substantial and context of the Provincial Budget of the 2017 Fiscal Year. Opinion from Castetter (1996) reveals that the pattern form interactions used include the dissemination of public Issues, issues of interest groups to support or oppose the Budget preparation process. Second, is the pattern of associative systemic interactions. The Systemic interaction pattern is a model of the relationship between the executive and the legislature strongly influenced by the political, economic, and social systems. So that in the context of the executive and legislative regions in preparing public budgets, namely the preparation of the General Budget Policy (KUA) and the Priority and Budget Platform (PPAS) are not free of value from the interests and demands of various interest groups. The pattern of forming interests from one group that has greater political resources and power compared to other groups tends to influence budget policy decisions.

Anderson (1979) et al. in Sugiyono (2013) Other designations for actors in the public policy process are Legislators, Executives, Judicial Institutions, Pressure Groups, Political Parties, Mass Media, Community Organizations, Administrative or Bureaucratic Apparatuses, Non-Governmental Organizations / NGOs, Private groups, think tanks and shadow cabinet groups. According to Anderson (1979), Lindblom (1980), and Lester (2000), actors in the formulation of policies are official and official actors consisting of Government Agencies (bureaucracy), Presidents (executives), Legislative Institutions and Judicial Institutions. As for the cast and unofficial consisting of interest groups (which can be seen from the number of members, financial capacity, other sources and skills owned by its members), political parties, and individual citizens. Actors in the public policy process in Indonesia consist of Presidential Institutions, Parliament, Bureaucrats, Judiciary Institutions, Political Parties, interest groups, mass media and campus 
intellectual groups and non-campus groups (Moenir, 2008).

The conclusion is that the first is the process of budgeting the Regional Revenue and Expenditure Budget (APBD), especially in the field of development there are differences in the interests brought by the executive and legislative branches. Executive interests are the articulations of various interests that enter through formal mechanisms, namely Musrenbangda, starting from the village / village level, sub-district and district levels. The second interest comes from the proposals or input of programs for each Regional Work Unit (SKPD) and the budget needed by them to carry out their functions. While the interests of the legislature come from two things, namely the interests of the public in a smaller scope, namely the constituency of the constituency in which he represents. The interests originating from these constituents are accommodated by each member of the Regional House of Representatives through the Community Aspiration Network (Jasmas) mechanism. Then the two different interests between the executive and the legislature, which try to be united into one understanding of the two institutions.

To reach an agreement or understanding, negotiations are carried out. Negotiations carried out by the two parties were carried out through two mechanisms, namely formal and informal mechanisms. This formal mechanism is carried out through formal forums or meetings both in the internal area and involving both parties. The informal mechanism is implemented after official forums. This is used as an effective step to overcome deadlock situations in the budgeting process. The impact of the negotiation of interests is the shifting of the budget or the reduction of allocations which are then put into other posts according to the agreement of the budget agency and the executive budget team. It is also included in the next fiscal year so that there is a transactional process in the informal mechanism. Then the two different interests between the executive and the legislature, which try to be united into a mutual understanding of the two institutions. To reach an agreement or an agreement is carried out negotiations. Negotiations carried out by the two parties were carried out through two mechanisms, namely formal and informal mechanisms. This formal mechanism is carried out through formal forums or meetings both in the internal area and involving both parties. The informal mechanism is implemented after official forums. This is used as an effective step to overcome deadlock situations in the budgeting process. The impact of the negotiation of interests is the shifting of the budget or the reduction of allocations which are then put into other posts according to the agreement of the budget agency and the executive budget team. It is also included in the next fiscal year so that there is a transactional process in the informal mechanism.

The third thing, there are several factors that influence the outcome of the policy and then affect the public interest in terms of the budget is the accommodation of all interests in the Regional Budget Revenue and Expenditure through the budgeting process. However, because the budget that is owned is relatively large, the budget cannot be beaten evenly, so that the priority and super priority of several public interests are chosen. Then the budget is allocated to priority posts based on problems faced by the community. For example, budget allocations for education, health and infrastructure are greater than in other sectors. In addition, the implication of the budgeting process is the fulfillment of all public interests as a whole, not just the sectoral public interest or constituency of the constituency where the representative is elected. In addition there are public interests that are not accommodated so that they are included in the budgeting process for the next fiscal year. In terms of public services, the implications for the public when viewed from the allocation of the Regional Revenue and Expenditure Budget (APBD) are still very minimal.

\section{CONCLUSIONS AND RECOMMENDATIONS}

ns directly or indirectly involved in the process of implementing E-Budgeting policies, it can be concluded as follows:

a) The role of the executive in implementing the EBudgeting policy is particularly evident in the process of determining the budget for each work program that has been agreed to become the Local Government Work Plan (RKPD);

b) The role of the legislature lies in the process of discussing and granting approval to the budget proposed by the executive;

c) The role of other institutions, communities and nongovernmental organizations (NGOs) in the process of implementing the E-Budgeting policy is to provide input on priority programs and activities that should be funded by the Dearah 
Government, and oversee budget planning if it is in line with community needs;

\section{SUGGESTION}

Based on the inhibiting factors described in the above conclusions, the researcher can propose the following suggestions: fostering harmonious relations between the executive and legislative branches, through continuous communication and coordination, so as to facilitate "political compromises" in the APBD preparation process; which can be done by providing "more flexible space" in the budget allocation process, so that the aspirations and interests of DPRD members can be contained in the APBD, but they must still be based on the interests of the wider community.

\section{REFERENCES}

Aderson, James, 1979. Public Policy Making. Renehart and Winston: New York.

Aditya, Bayu Rizky et. al. 2020. Sinergitas Stakeholder Untuk Administrasi Publik Yang Demokratis Dalam Persepekif Teori Governance (Studi Pada Tempat Pengelolaan Sampah Terpadu Mulyoagung Bersatu Kecamatan Dau, Kabupaten Malang). (Jurnal Administrasi Publik (JAP), Vol 2, No. 3).

Alwasilah, A. Chaedar, 2002. Pokoknya Kualitatif : Dasar-dasar Merancang dan Melakukan Penelitian Kualitatif. Jakarta: Pustaka Jaya.
Babbie, Earl. 2004. The Practice of Social Research: 10th Edition, Belmont:Wadsworth/Thomson Learning.

Castetter, Wiliam B. (1996). The Human Resource Function In Educational Administration. NewJersy: Prentince Hall,Inc.

Chase, Wareen., Fred Bown. (1992). General Statistics. New York: Allyn and Bacon.

Dwiyanto, Agus. 2015. Mewujudkan Good Governance Melalui Pelayanan Publik, Yogyakarta: Gajah Mada University Press.

Erianto, Dwi, 2015. "Kisruh APBD DKI Jakarta". Dalam Kronologi, Balitbang Kompas, 19 Maret 2015.

Indrajit, Richardus Eko, 2002. Electronic Government: Strategi Pembangunan dan Sistem Pelayanan Publik Berbasis Teknologi Digital. Yogyakarta: Penerbit Andi.

Mardalis. 2003. Metode Penelitian suatu Pendekatan proposal, Jakarta: Bumi Aksara.

Miles, Matthew B.; dan Huberrman, A. Michael; dan Saldana, Johnny; 2014. Qualitative Data Analysis: A Methods Sourcebook. Singapore: SAGE Publications Inc.

Moenir, A.S. 2008. Manajemen pelayanan Umum di Indonesia, Jakarta: Bumi Aksara.

Napitupulu. 2007. Seri IImu Pemerintahan: Menakar Urgensi Otonomi Daerah: Solusi Atas Ancaman Disintegrasi, Jakarta : Alumni.

Sabaruddin, abdul. 2015. Manajemen Kolaborasi dalam Pelayanan Publik, Yogyakarta: Graha IImu.

Strauss, Anselm dan Juliet Corbin. 1997. Dasar-Dasar Penelitian Kualitatif Prosedur, Tehnik, dan Teori. Surabaya: Bina IImu Ofset.

Sugiyono. 2013. Metode Penelitian Kuantitatif, Kualitatif dan R\&D. Bandung: Alfabeta.CV.

Received on 25-11-2020

Accepted on 31-12-2020

Published on 18-01-2021

DOI: https://doi.org/10.6000/1929-4409.2021.10.19

(c) 2021 Hakim et al.; Licensee Lifescience Global.

This is an open access article licensed under the terms of the Creative Commons Attribution Non-Commercial License (http://creativecommons.org/licenses/by-nc/3.0/) which permits unrestricted, non-commercial use, distribution and reproduction in any medium, provided the work is properly cited. 